\title{
EFFICIENCY OF SPICE EXTRACTS IN SOYBEAN OIL STABILITY DURING HEATING
}

\author{
Simara Pícoli Pitaro ${ }^{1}$, Débora Maria Moreno Luzia ${ }^{2}$, Ana Carolina da Silva ${ }^{1 凶}$, Neuza Jorge ${ }^{1}$ \\ ${ }^{1}$ Department of Food Engineering and Technology, São Paulo State University, 15054-000, São José do Rio \\ Preto, SP, Brazil \\ ${ }^{2}$ Department of Exact and Earth Sciences, Minas Gerais State University, 38200-000, Frutal, MG, Brazil

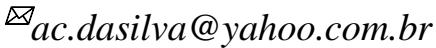 \\ https://doi.org/10.34302/crpjfst/2020.12.1.10

\begin{tabular}{|c|c|}
\hline Article history: & ABSTRACT \\
\hline ived: & \multirow{10}{*}{$\begin{array}{l}\text { The aim of the present study was to evaluate the efficiency of spice } \\
\text { extracts in soybean oil stability regarding oxidative deterioration during } \\
\text { heating. The treatments i) soybean oil (Control), ii) soybean oil with thyme } \\
\text { extract (TE), iii) soybean oil with basil and thyme extracts (Mixture } 1 \text { ), iv) } \\
\text { soybean oil with oregano and thyme extracts (Mixture } 2 \text { ), and v) soybean } \\
\text { oil with tert-butyl-hydroquinone (TBHQ) were subjected to } 180^{\circ} \mathrm{C} \text { for } 30 \\
\text { h; the samples were taken at the times } 0,5,10,15,20,25 \text {, and } 30 \mathrm{~h} \text { and } \\
\text { analyzed as to peroxide value, conjugated dienoic acids, oxidative stability, } \\
\text { total polar compounds, fatty acid and triacylglycerol composition. The } \\
\text { spice extracts improved soybean oil resistance against thermal } \\
\text { deterioration and, therefore, they may be recommended as sources of } \\
\text { powerful antioxidant for stabilization of unsaturated vegetable oils. }\end{array}$} \\
\hline 13 February 2019 & \\
\hline & \\
\hline 3 February 2020 & \\
\hline Keywords: & \\
\hline xidation; & \\
\hline Fatty acids; & \\
\hline & \\
\hline Polar compounds; & \\
\hline Oxidative stability. & \\
\hline
\end{tabular}

\section{Introduction}

Lipid oxidation has been recognized as the main problem that affects edible oils, causing changes in their chemical, sensory, and nutritional properties (Velasco and Dobarganes, 2002). It is known that the products from lipid oxidation are associated with several risks to health, such as aging, heart diseases and cancer. The addition of antioxidants is effective at delaying lipid oxidation (Suja et al., 2004). However, there is concern related to the possible adverse effects that synthetic antioxidants, obtained by several diet components, may cause to health. Therefore, it is important to indentify new natural components in foods that present antioxidant activity (Hemalatha and Ghafoorunissa, 2007).

From the point of view of the current consumer, aspects such as safety, health, and quality become pertinent on agriculture and food production. In those circumstances, research and development of safe natural antioxidants in order to replace synthetic antioxidants have been performed, by the use of sources such as citric fruit seeds (Luzia and Jorge, 2013), spices (Hossain et al., 2010), and medicinal plants (Krishnaiah et al., 2011).

Spices are natural products that have been used not only as flavoring and coloring agents, but also as food additives, as well as in popular medicine, and all over the world for thousands of years. Many spices have also been recognized due to their digestive, carminative, antibacterial, antiinflammatory, antimutagenic actions, their anticancer potential, etc (Ceylan and Fung, 2004; Srinivasan, 2005). Spices are important antioxidant sources in daily intake, especially in food cultures in which they are regularly used in the form of fresh, dried, or dehydrated herbs (Carlsen et al., 2010).

The antioxidant potential of spices is due to the presence of certain phytochemicals, generically named as phenolic compounds, 
such as rosmarinic and caffeic acids in rosemary, salvia, oregano and thyme (Pukalskas et al., 2005; Shan et al., 2005; Hashemi and Haghighi, 2018).

Basil (Ocimum basilicum L.), which is originated from Southeastern Asia and Central Africa, is an aromatic herb that is traditionally used in the treatment of headaches, diarrhea, constipation, moles, worms, and renal disorders (Simon et al., 1999). It is also source of aroma and essential oils which contain biologically active compounds with antimicrobial properties (Wannissorn et al., 2005). Oregano (Origanum vulgare L.) is one of the most popular seasonings in the world, with highly favorable flavor for consumers; it is widely used for its antimicrobial and antioxidant properties. Thyme (Thymus vulgaris L.), which has its main center of dispersion in the Mediterranean region, is a plant that is distributed all over the world. It has commonly been used as spice in cooking, in order to add flavor to dishes (Yanishlieva et al., 2006).

Although literature shows antioxidant properties of spice extracts, there is no information that describes the extract efficiency in soybean oil oxidative stability. Thus, the aim of this study was to evaluate the spice extract efficiency in soybean oil stability regarding oxidative deterioration during heating.

\section{Materials and methods}

\subsection{Materials}

\subsubsection{Spices}

In order to perform the experiments, basil (Ocimum basilicum L.), oregano (Origanum vulgare L.), and thyme (Thymus vulgaris L.), were purchased in natura, in the market of São José do Rio Preto-SP, Brazil; damaged leaves, stems, and roots were removed. Then, the spices were subjected to drying in an oven, at $40{ }^{\circ} \mathrm{C}$, for $24 \mathrm{~h}$. After dehydration, the materials were ground and passed in tyler sieve 3.5, with $5.66 \mathrm{~mm}$ opening, for obtainment of the extracts.

\subsubsection{Oil}

In order to perform the experiment, refined soybean oil with no addition of synthetic antioxidants (TBHQ and citric acid) was used. The soybean oil was processed by the company
Cargill Agrícola S/A, Uberlândia-MG, Brazil, and came in packages of $900 \mathrm{~mL}$.

\subsubsection{Antioxidants}

The synthetic antioxidant used was tertbutyl-hydroquinone $(50 \mathrm{mg} / \mathrm{kg})$ (TBHQ), presented in the form of powder, provided by the company Danisco S/A, Cotia-SP, Brazil. In order to obtain the thyme, basil, and oregano ethanolic extracts, $25 \mathrm{~g}$ of spices were added to $75 \mathrm{~mL}$ of ethanol, mixed, under intense agitation, for $30 \mathrm{~min}$. Then, they were filtered in vacuum pump, and the supernatants were separated from the precipitates. The removal of the solvent used for extract obtainment was performed in rotary evaporator, under reduced pressure, at $40{ }^{\circ} \mathrm{C}$, with the purpose of determining, by direct weighing, the extraction yields. Each extract was applied at a concentration of $2,000 \mathrm{mg} / \mathrm{kg}$ in soybean oil.

\subsubsection{Experimental Essay}

Five treatments were subjected to thermoxidation and conducted in two repetitions: i) soybean oil (Control), ii) soybean oil with thyme extract (TE), iii) soybean oil with basil and thyme extracts (Mixture 1), iv) soybean oil with oregano and thyme extracts (Mixture 2), and v) soybean oil with terc-butylhydroquinone (TBHQ). In this essay, the treatments were conducted in a heated plate, using $50 \mathrm{~mL}$ beakers containing $40 \mathrm{~mL}$ of sample, with surface/volume relation of $0.4 / \mathrm{cm}$. This value corresponds to what is normally used in deep frying. The temperature used was $180{ }^{\circ} \mathrm{C}$, which is normally employed in immersion frying. The essay was conducted discontinuously, with $10 \mathrm{~h}$ of heating/day; the samples were taken at different periods of time $(0,5,10,15,20,25$, and $30 \mathrm{~h})$. The temperature was controlled with the assistance of a thermometer. All samples, at different time intervals, were collected in amber glass in the presence of inert gas $\left(\mathrm{N}_{2}\right)$ and stored at approximate temperature of $-18{ }^{\circ} \mathrm{C}$ until the moment of analyses. 


\subsection{Methods}

\subsubsection{Peroxide Value}

Determined in potentiometric titrator (Metrohm Ltd., Herisau, Switzerland), model 793, according to the method Cd 8b-90 (AOCS 2009), expressed as meq $\mathrm{O}_{2} / \mathrm{kg}$.

\subsubsection{Conjugated Dienoic Acids}

Determined in spectrophotometer (Shimadzu, Chiyoda-ku, Tokyo, Japan), model Uv-Vis mini 1240, according to the method $\mathrm{Ti}$ 1A-64 (AOCS, 2009), expressed as \%.

\subsubsection{Oxidative Stability}

Determined in Rancimat (Metrohm Ltd., Herisau, Switzerland), model 743, according to the methodology Cd 12b-92 (AOCS, 2009). Oil samples ( $3 \mathrm{~g})$ were transferred to reaction tubes and subjected to oxidation at temperature of $100{ }^{\circ} \mathrm{C}$, with $20 \mathrm{~L} / \mathrm{h}$ airflow. The curve of electrical conductivity versus time was automatically registered during the oxidation reaction and the induction period was expressed in $\mathrm{h}$.

\subsubsection{Total Polar Compounds}

Determined by the chromatographic method proposed by Dobarganes et al. (2000). The level of polar compounds, polar fraction, was calculated regarding the unaltered triacylglycerols, considering that the retained polar compounds were included in the polar fraction. The results, obtained through column chromatography, were expressed as percentage.

\subsubsection{Fatty Acids}

Determined by chromatography in gaseous phase, with previous esterification of the samples, according to the procedure described by Ce 2-66 (AOCS, 2009). For fatty acid determination, the method Ce 1-62 (AOCS, 2009) was used, with adaptations. The analysis was performed in CG (Varian Inc., Walnut Creek, CA, USA), model 3900, with flame ionization detector, split injector, and automatic sampler. Analysis conditions: fused silica capillary column (CP-Sil 88, Microsorb, Varian Inc., Walnut Creek, CA, USA) of $60 \mathrm{~m}$ length, with $0.25 \mathrm{~mm}$ internal diameter and $0.20 \mu \mathrm{m}$ film thickness. The programming of the column temperature was initiated at $90{ }^{\circ} \mathrm{C}$, for $4 \mathrm{~min}$, heated at $10 \mathrm{C} / \mathrm{min}$ until $195{ }^{\circ} \mathrm{C}$, and kept isothermal for $16 \mathrm{~min}$. The temperatures used in the injector and detector were 230 and $250{ }^{\circ} \mathrm{C}$, respectively. The carrier gas was hydrogen with $30 \mathrm{~mL} / \mathrm{min}$ linear speed. The fatty acids were identified by comparison of retention times of fatty acid methyl ester pure standards with separated sample components and the quantification was performed by area normalization. A mixture compound of 37 fatty acid methyl esters was used as standard (Supelco, Bellefonte, USA) from C4:0 to C24:1, with purity between 99.1 and $99.9 \%$.

\subsubsection{Triacylglycerol Composition}

Determined by using the computer program developed by Antoniosi Filho and co-workers (1995), which considers the fatty acid composition of the samples.

\subsection{Experimental Delineation}

The experiment was performed in factorial scheme, in completely randomized delineation. Variance analysis and Tukey test at 5\% were obtained by the program ESTAT - System for Statistical Analyses, version 2.0.

\section{Results and discussions}

The evaluation of oxidation parameters represents the difference between formation and decomposition of peroxides, primary oxidation products, colorless and odorless (Silva and Jorge, 2014).

In Table 1, during heating, an oscillation of peroxides is observed in the treatments, due to their formation and degradation in lipid oxidation secondary compounds. In the final heating time, it is observed that the antioxidants did not present significant difference concerning the peroxide formation, when compared with Control. According to Dysseler and Dieffenbacher (2000), since peroxides decompose at $150{ }^{\circ} \mathrm{C}$, it is difficult to follow their accumulation during the heating times.

When fatty acids of polyunsaturated oils are 
oxidized, especially linoleic and linolenic acids, conjugated dienes are formed. This conjugated structure highly absorbs ultraviolet light in the wavelength between 232 and $234 \mathrm{~nm}$ (Kulas and Ackman, 2001).

In Table 1, it can be noticed, concerning heating times for each treatment, that the levels of conjugated dienoic acids increased gradually, during the thermoxidation process, from the beginning to the end of heating, from 0.3 to $3.3 \%$ in Control, from 0.3 to $2.5 \%$ in TE, from 0.3 to $2.6 \%$ in Mixture 1, from 0.3 to $2.6 \%$ in Mixture 2, and from 0.3 to $2.9 \%$ in TBHQ.

In the treatments inside each heating time, it is verified that, initially, there was no significant difference of diene levels in all the treatments. However, after heating was initiated, the natural antioxidants presented higher antioxidant action, differing significantly from Control and from TBHQ, which presented, in the time of $30 \mathrm{~h}$, reduction of $24.1 \%, 19.8 \%$, and $21.0 \%$ in the formation of conjugated dienes, respectively, in TE, Mixture 1, and Mixture 2.

The oxidative stability is defined as the time to reach detectable rancidity level or change in the oxidation rate and is directly influenced by the presence of antioxidant which, in its turn, suffers the action of high temperatures. It is observed, in Table 1, that during heating, soybean oil had severe decrease in the induction period, which was expected, since it is free from antioxidant addition and since it only contains antioxidants that are naturally present, such as tocopherols. Nevertheless, soybean oil added TBHQ also presented high oxidative stability loss, while the spice extracts, especially thyme, were more efficient in the protection of oil against oxidation.

Table 1. Influence of antioxidants on the analytical measures performed in soybean oil during heating at $180^{\circ} \mathrm{C}$.

\begin{tabular}{|c|c|c|c|c|c|c|c|}
\hline \multirow{2}{*}{ Treatments } & \multicolumn{7}{|c|}{ Heating times $(\mathrm{h})$} \\
\hline & 0 & 5 & 10 & 15 & 20 & 25 & 30 \\
\hline \multicolumn{8}{|c|}{ Peroxide value (meq/kg) } \\
\hline Control & $0.7 \pm 0.0^{\mathrm{dB}}$ & $4.1 \pm 0.4^{\mathrm{bC}}$ & $2.0 \pm 0.0^{\mathrm{cdC}}$ & $6.2 \pm 0.0^{\mathrm{aA}}$ & $2.9 \pm 0.3^{\mathrm{bcA}}$ & $3.9 \pm 0.0^{\mathrm{bcA}}$ & $2.5 \pm 0.0^{\mathrm{bcdA}}$ \\
\hline TE & $1.6 \pm 0.2^{\mathrm{cAB}}$ & $10.5 \pm 0.6^{\mathrm{aA}}$ & $3.3 \pm 0.5^{\mathrm{bcBC}}$ & $3.9 \pm 0.5^{\mathrm{bBC}}$ & $3.7 \pm 0.3^{\mathrm{bA}}$ & $4.1 \pm 0.0^{\mathrm{bA}}$ & $3.6 \pm 0.0^{\mathrm{bcA}}$ \\
\hline Mixture 1 & $2.1 \pm 0.0^{\mathrm{dAB}}$ & $7.3 \pm 0.4^{\mathrm{aB}}$ & $5.5 \pm 0.3^{\mathrm{abA}}$ & $5.0 \pm 0.9^{\mathrm{bcAB}}$ & $3.4 \pm 0.2^{\mathrm{cdA}}$ & $4.0 \pm 0.1^{\mathrm{bcdA}}$ & $3.7 \pm 0.2^{\mathrm{bcdA}}$ \\
\hline Mixture 2 & $2.7 \pm 0.0^{\mathrm{cA}}$ & $7.1 \pm 0.1^{\mathrm{aB}}$ & $4.3 \pm 0.5^{\mathrm{bcAB}}$ & $6.1 \pm 0.1^{\mathrm{abA}}$ & $4.1 \pm 0.1^{\mathrm{cA}}$ & $4.5 \pm 0.0^{\mathrm{bcA}}$ & $4.1 \pm 0.2^{\mathrm{cA}}$ \\
\hline TBHQ & $0.8 \pm 0.0^{\mathrm{cB}}$ & $6.1 \pm 0.3^{\mathrm{aB}}$ & $1.8 \pm 0.0^{\mathrm{bcC}}$ & $3.2 \pm 0.0^{\mathrm{bC}}$ & $2.6 \pm 0.9^{\mathrm{bcA}}$ & $1.9 \pm 0.0^{\mathrm{bcB}}$ & $2.5 \pm 0.0^{\mathrm{bcA}}$ \\
\hline \multicolumn{8}{|c|}{ Conjugated dienoic acids (\%) } \\
\hline Control & $0.3 \pm 0.0^{\mathrm{gA}}$ & $1.7 \pm 0.0^{\mathrm{fA}}$ & $2.3 \pm 0.0^{\mathrm{eA}}$ & $2.5 \pm 0.0^{\mathrm{dA}}$ & $2.8 \pm 0.0^{\mathrm{cA}}$ & $2.9 \pm 0.1^{\mathrm{bA}}$ & $3.3 \pm 0.0^{\mathrm{aA}}$ \\
\hline TE & $0.3 \pm 0.0^{\mathrm{eA}}$ & $0.9 \pm 0.0^{\mathrm{dD}}$ & $1.7 \pm 0.0^{\mathrm{cB}}$ & $2.2 \pm 0.0^{\mathrm{bB}}$ & $2.3 \pm 0.0^{\mathrm{bBC}}$ & $2.4 \pm 0.0^{\mathrm{abD}}$ & $2.5 \pm 0.0^{\mathrm{aC}}$ \\
\hline Mixture 1 & $0.3 \pm 0.0^{\mathrm{fA}}$ & $1.1 \pm 0.0^{\mathrm{eC}}$ & $1.4 \pm 0.0^{\mathrm{dC}}$ & $2.1 \pm 0.0^{\mathrm{cC}}$ & $2.2 \pm 0.0^{\mathrm{bC}}$ & $2.0 \pm 0,0^{\mathrm{aBC}}$ & $2.6 \pm 0.0^{\mathrm{aC}}$ \\
\hline Mixture 2 & $0.3 \pm 0.0^{\mathrm{eA}}$ & $1.0 \pm 0.0^{\mathrm{dCD}}$ & $1.2 \pm 0.0^{\mathrm{dD}}$ & $2.2 \pm 0.0^{\mathrm{cBC}}$ & $2.4 \pm 0.0^{\mathrm{bB}}$ & $2.5 \pm 0.0^{\mathrm{abCD}}$ & $2.6 \pm 0.0^{\mathrm{aC}}$ \\
\hline TBHQ & $0.3 \pm 0.0^{\mathrm{eA}}$ & $1.6 \pm 0.0^{\mathrm{dB}}$ & $2.3 \pm 0.0^{\mathrm{cA}}$ & $2.5 \pm 0.0^{\mathrm{bA}}$ & $2.6 \pm 0.0^{\mathrm{bA}}$ & $2.7 \pm 0.0^{\mathrm{bB}}$ & $2.9 \pm 0.0^{\mathrm{aB}}$ \\
\hline \multicolumn{8}{|c|}{ Oxidative stability (h) } \\
\hline Control & $15.6 \pm 0.0^{\mathrm{aB}}$ & $8.1 \pm 0.0^{\mathrm{bB}}$ & $7.4 \pm 0.0^{\mathrm{bcB}}$ & $6.8 \pm 0.4^{\mathrm{cBC}}$ & $3.0 \pm 0.0^{\mathrm{dC}}$ & $2.5 \pm 0.0^{\mathrm{dC}}$ & $2.3 \pm 0.1 \mathrm{dD}$ \\
\hline TE & $16.4 \pm 0.0^{\mathrm{aB}}$ & $10.1 \pm 0.0^{\mathrm{bA}}$ & $9.3 \pm 0.0^{\mathrm{bA}}$ & $9.0 \pm 0.5^{\mathrm{bA}}$ & $7.3 \pm 0.2^{\mathrm{cA}}$ & $6.0 \pm 0.2^{\mathrm{dA}}$ & $5.7 \pm 0.1^{\mathrm{dA}}$ \\
\hline Mixture 1 & $16.5 \pm 0.2^{\mathrm{aB}}$ & $10.3 \pm 0.1^{\mathrm{bA}}$ & $10.0 \pm 0.0^{\mathrm{bA}}$ & $6.4 \pm 0.2^{\mathrm{cC}}$ & $6.6 \pm 0.2^{\mathrm{cdAB}}$ & $5.3 \pm 0.1^{\mathrm{dAB}}$ & $3.9 \pm 0.1^{\mathrm{bE}}$ \\
\hline Mixture 2 & $16.3 \pm 0.1^{\mathrm{aB}}$ & $10.5 \pm 0.2^{\mathrm{bA}}$ & $10.0 \pm 0.0^{\mathrm{bA}}$ & $7.8 \pm 0.0^{\mathrm{cB}}$ & $6.1 \pm 0.2^{\mathrm{dB}}$ & $4.8 \pm 0.1^{\mathrm{eB}}$ & $3.7 \pm 0.4^{\mathrm{eBC}}$ \\
\hline TBHQ & $22.6 \pm 0.0^{\mathrm{aA}}$ & $8.3 \pm 0.0^{\mathrm{bB}}$ & $7.7 \pm 0.1^{\mathrm{bB}}$ & $3.8 \pm 0.0^{\mathrm{cD}}$ & $3.4 \pm 0.0^{\mathrm{cC}}$ & $3.0 \pm 0.0^{\mathrm{cC}}$ & $2.6 \pm 0.0^{\mathrm{cCD}}$ \\
\hline \multicolumn{8}{|c|}{ Total polar compounds $(\%)$} \\
\hline Control & $4.4 \pm 0.0^{\mathrm{gA}}$ & $18.9 \pm 0.0^{\mathrm{fA}}$ & $23.3 \pm 0.0^{\mathrm{eA}}$ & $38.1 \pm 0.1^{\mathrm{dA}}$ & $40.7 \pm 0.4^{\mathrm{cA}}$ & $45.1 \pm 0.3^{\mathrm{bA}}$ & $57.3 \pm 0.0^{\mathrm{aA}}$ \\
\hline TE & $4.2 \pm 0.0^{\mathrm{gA}}$ & $10.7 \pm 0.6^{\mathrm{fC}}$ & $14.4 \pm 0.4^{\mathrm{eC}}$ & $24.1 \pm 0.0^{\mathrm{dE}}$ & $26.1 \pm 0.1^{\mathrm{cE}}$ & $27.8 \pm 0.0^{\mathrm{bE}}$ & $30.8 \pm 0.2^{\mathrm{aE}}$ \\
\hline Mixture 1 & $5.4 \pm 0.1^{\mathrm{gA}}$ & $14.8 \pm 0.6^{\mathrm{fB}}$ & $19.3 \pm 0.0^{\mathrm{eB}}$ & $32.3 \pm 0.2^{\mathrm{dC}}$ & $35.3 \pm 0.1^{\mathrm{cC}}$ & $39.3 \pm 0.1^{\mathrm{bC}}$ & $42.8 \pm 0.2^{\mathrm{aC}}$ \\
\hline Mixture 2 & $5.2 \pm 0.0^{\mathrm{gA}}$ & $9.6 \pm 0.0^{\mathrm{fC}}$ & $11.3 \pm 0.1 \mathrm{eD}$ & $29.3 \pm 0.6^{\mathrm{dD}}$ & $32.1 \pm 0.0^{\mathrm{cD}}$ & $35.5 \pm 0.4^{\mathrm{bD}}$ & $39.0 \pm 0.3^{\mathrm{aD}}$ \\
\hline TBHQ & $5.4 \pm 0.1^{\mathrm{gA}}$ & $16.1 \pm 0.1^{\mathrm{fB}}$ & $20.2 \pm 0.0^{\mathrm{eB}}$ & $34.5 \pm 0.2^{\mathrm{dB}}$ & $37.0 \pm 0.2^{\mathrm{cB}}$ & $40.7 \pm 0.3^{\mathrm{bB}}$ & $52.9 \pm 0.2^{\mathrm{aB}}$ \\
\hline
\end{tabular}

Control: soybean oil; TE: soybean oil with thyme extract; Mixture 1: soybean oil with thyme and basil extracts; Mixture 2: soybean oil with thyme and oregano extracts; TBHQ: soybean oil with tert-butyl-hydroquinone.

a, b...(line) and A, B...(column): means followed by the same letter do not differ by Tukey test $(\mathrm{p}>0,05)$. 
Until $10 \mathrm{~h}$, it can be seen in Table 1 that, TE and Mixtures 1 and 2 did not present significant difference and, from $15 \mathrm{~h}$ on, TE showed higher stability until final time, thus, not presenting synergism among the spice extracts.

In a study performed by Ramalho and Jorge (2008), the addition of rosemary extract to soybean oil, under heating at $180{ }^{\circ} \mathrm{C}$, for 10 $\mathrm{h}$, presented higher stability to oil when compared with the addition of synthetic antioxidants. In the present study, the results obtained regarding the oxidative stability indicated that the antioxidant capacity of spice extracts was higher, when compared with the synthetic antioxidant TBHQ after the beginning of heating.

The determination of the total quantity of alteration products, originated as a consequence of high temperature processes, constitutes the base for oil use limitation in some countries, established around 24-27\% of polar compounds (Firestone et al., 1991). Table 1 shows that there was an increase in the value of total polar compounds, in all treatments, with the increase of heating times. Control ranged from 4.4 to $57.3 \%$, TE from 4.2 to $30.8 \%$, Mixture 1 from 5.4 to $42.8 \%$, Mixture 2 from 5.2 to $39.0 \%$, and TBHQ from 5.4 to $52.9 \%$.

In the treatments inside each heating time, it is verified that, at initial time, there was no significant difference in the levels of polar compounds in all treatments. It is noticed that, in the final time, at $30 \mathrm{~h}$ of heating, TE $(30.8 \%)$ presented higher protection to soybean oil, retarding the formation of polar compounds in $46.2 \%$ and differing significantly from all the other treatments.

In Brazil, there is no legislation that establishes a maximum limit for polar compound value in oils heated in high temperatures. After $20 \mathrm{~h}$, at $180{ }^{\circ} \mathrm{C}$, all treatments exceeded $25 \%$, maximum limit recommended by International Legislation.

It can be observed in Table 2 that the values of fatty acid composition, in the initial oils found in this study, are close to those reported by Gunstone (1996), who establishes values of 15,22 , and $61 \%$ of saturated, C18:1, and C18:2 $+\mathrm{C} 18: 3$ fatty acids, respectively, for soybean oil.

When evaluating the means of fatty acid composition in the treatments during the heating process, a significant difference was verified $(\mathrm{p}<0,05)$, with an increase in the percentage of saturated and C18:1 fatty acid, and a decrease in the quantity of C18:2 + C18:3, which are considered essential fatty acids.

Table 2. Means of saturated and C18:2 + C18:3 fatty acids in soybean oil during heating at $180^{\circ} \mathrm{C}$.

\begin{tabular}{|c|c|c|c|}
\hline \multirow{2}{*}{ Treatments } & \multicolumn{3}{|c|}{ Heating times $(\mathrm{h})$} \\
\hline & 0 & 15 & 30 \\
\hline \multicolumn{4}{|c|}{ Saturated $(\%)$} \\
\hline Control & $13.6^{\mathrm{cE}}$ & $16.3^{\mathrm{bB}}$ & $17.3^{\mathrm{aB}}$ \\
\hline $\mathrm{TE}$ & $14.1^{\mathrm{cA}}$ & $16.2^{\mathrm{bC}}$ & $16.4^{\mathrm{aD}}$ \\
\hline Mixture 1 & $13.9^{\mathrm{cB}}$ & $16.2^{\mathrm{bB}}$ & $17.3^{\mathrm{aB}}$ \\
\hline Mixture 2 & $13.8^{\mathrm{cC}}$ & $16.0^{\mathrm{bD}}$ & $16.9^{\mathrm{aC}}$ \\
\hline TBHQ & $13.7^{\mathrm{cD}}$ & $16.9^{\mathrm{bA}}$ & $19.0^{\mathrm{aA}}$ \\
\hline \multicolumn{4}{|l|}{ C18:1 (\%) } \\
\hline Control & $27.1^{\mathrm{cAB}}$ & $29.0^{\mathrm{bD}}$ & $30.1^{\mathrm{aC}}$ \\
\hline $\mathrm{TE}$ & $26.9^{\mathrm{cC}}$ & $28.8^{\mathrm{bE}}$ & $29.3^{\mathrm{aE}}$ \\
\hline Mixture 1 & $27.2^{\mathrm{cA}}$ & $29.3^{\mathrm{bB}}$ & $30.5^{\mathrm{aB}}$ \\
\hline Mixture 2 & $27.0^{\mathrm{cC}}$ & $29.4^{\mathrm{bA}}$ & $29.8^{\mathrm{aD}}$ \\
\hline TBHQ & $27.1^{\mathrm{cB}}$ & $29.2^{\mathrm{bC}}$ & $31.9^{\mathrm{aA}}$ \\
\hline \multicolumn{4}{|c|}{$\mathrm{C} 18: 2+\mathrm{C} 18: 3(\%)$} \\
\hline Control & $58.3^{\mathrm{aA}}$ & $54.1^{\mathrm{bB}}$ & $51.7^{\mathrm{cC}}$ \\
\hline $\mathrm{TE}$ & $57.8^{\mathrm{aC}}$ & $54.4^{\mathrm{bA}}$ & $53.7^{\mathrm{cA}}$ \\
\hline Mixture 1 & $57.8^{\mathrm{aC}}$ & $53.9^{\mathrm{bD}}$ & $51.3^{\mathrm{cD}}$ \\
\hline Mixture 2 & $58.2^{\mathrm{aB}}$ & $54.0^{\mathrm{bC}}$ & $52.6^{\mathrm{cB}}$ \\
\hline TBHQ & $58.2^{\mathrm{aB}}$ & $53.1^{\mathrm{bE}}$ & $47.8^{\mathrm{cE}}$ \\
\hline
\end{tabular}

Control: soybean oil; TE: soybean oil with thyme extract; Mixture 1: soybean oil with thyme and basil extracts; Mixture 2: soybean oil with thyme and oregano extracts; TBHQ: soybean oil with tert-butylhydroquinone.

$\mathrm{a}, \mathrm{b} . . .($ line) and A, B...(column): means followed by the same letter do not differ by Tukey test $(p>0,05)$.

Thus, Table 2 shows that, in the end of the heating process, the percentages of saturated fatty acids increased in 27.7, 16.3, 24.5, 23.0, and $39.2 \%$ in Control, TE, Mixture 1, Mixture 2 , and TBHQ, respectively. The same behavior was observed in $\mathrm{C} 18: 1$ fatty acid, resulting in an $11.0 \%$ increase in Control, $8.8 \%$ in TE, $12.2 \%$ in Mixture 1, $10.5 \%$ in Mixture 2, and 
$18.0 \%$ in TBHQ. Concerning essential fatty acids, there was a decrease of linoleic and linolenic acids in higher percentages in TBHQ $(17.7 \%)$, followed by Mixture 1 (11.3\%), Control (11.3\%), Mixture 2 (9.5\%), and TE (7.2\%).

According to Pantzaris (1998), the decrease in linoleic and linolenic acids content during the heating process is due to their destruction by oxidation, polymerization, among other factors, and should, thus, be an important quality test for oils.

With the results, it is possible to consider that, regardless of the treatments studied, there was an increase of the saturated and monounsaturated fatty acids.

Oils and fats are considered as complex samples, due to the great number of different triacylglycerols that form them. Therefore, triacylglycerol identification is a difficult process, in which the number of possible structural forms is high, compared with the number of present fatty acids.

Table 3 shows the main individual triacylglycerols composition, classified according to the number of carbons.

Table 3. Main triglycerides composition (\%) in soybean oil added thyme extract before and after heating at $180{ }^{\circ} \mathrm{C}$.

\begin{tabular}{|l|c|c|}
\hline \multirow{2}{*}{ Triglycerides } & \multicolumn{2}{|c|}{ Heating times (h) } \\
\cline { 2 - 3 } & 0 & 30 \\
\hline C50 & 1.1 & 1.5 \\
\hline POP & 2.2 & 2.6 \\
\hline PLP & 1.2 & 1.4 \\
\hline C52 & 2.6 & 3.5 \\
\hline PLS & 10.5 & 12.1 \\
\hline POO & 10.5 & 10.5 \\
\hline PLO & 1.6 & 1.2 \\
\hline PLL & \multicolumn{2}{|c|}{} \\
\hline PLaL & 2.8 & 3.2 \\
\hline C54 & 2.1 & 2.7 \\
\hline SLO & 2.8 & 2.8 \\
\hline OOO & 12.7 & 14.3 \\
\hline SLL & 25.4 & 24.8 \\
\hline OLO & 3.8 & 2.8 \\
\hline OLL & 17.0 & 14.3 \\
\hline OLaL & 3.8 & 2.5 \\
\hline LLL & & \\
\hline LLaL & &
\end{tabular}

P: palmitic acid; S: stearic; O: oleic; L: linoleic; La: $\alpha$-linolenic acid.
For the determination of this composition, the main triacylglycerols represent the components of higher concentrations in the isomer, in which the number of carbons ranged from 50 to 54 . Due to the high level of soybean oil unsaturation, the main species of each group are the ones that have two or three unsaturated acids as major. Therefore, a significant number of unsaturated fatty acids is found in the composition of the main triacylglycerols.

\section{Conclusions}

The results show that the application of natural antioxidants avoids lipid oxidation during heating processes, making possible the effect on the results found of synergism or antagonism among the antioxidants added to soybean oil. Thyme and mixtures extract in the $2,000 \mathrm{mg} / \mathrm{kg}$ concentration are efficient, when compared with the synthetic antioxidant, TBHQ, stabilization, in the $50 \mathrm{mg} / \mathrm{kg}$ concentration, used by vegetable oil industries. The extracts improve soybean oil resistance against the deteriorative thermal alterations and, therefore, the spice extracts may be recommended as sources of powerful antioxidants for stabilization of food systems, especially in unsaturated vegetable oils.

\section{References}

Antoniosi Filho, N.R., Mendes, O.L., Lanças, F.M. (1995). Computer prediction of triacilglycerol composition of vegetable oils by HRGC. Chromatographia, 40(9), 557-562.

AOCS Official and tentative methods of the American Oil Chemists' Society (2009), American Oil Chemists' Society Press (6th Ed), Champaign.

Carlsen, M.H., Halvorsen, B.L., Holte, K., Bøhn, S.K., Dragland, S., Sampson, L., Willey, C., Senoo, H., Umezono, Y., Sanada, C., Barikma, I., Berhe, N., Willett, W.C., Philips, K.M., Jacobs Jr, D.R., Blomhoff, R. (2010). The total antioxidant content of more than 3100 foods, beverages, spices, herbs and supplements used worldwide. Nutrition Journal. 9(3), 1- 
11.

Ceylan, E., Fung, D.Y.C. (2004). Antimicrobial activity of spices. Journal of Rapid Methods and Automation in Microbiology, 12(1), 1-55.

Dobarganes, M.C., Velasco, J., Dieffenbacher, A. (2000). Determination of polar compounds polymerized and oxidized triacylglycerols, and diacylglycerols in oils and fats. Pure and Applied Chemistry, 72(8), 1563-1575.

Dysseler, P., Dieffenbacher, A. (2000). The importance of analytical data in fat technology. In IUPAC Workshop on fats, oils and oilseed analysis. EMBRAPA Book of Conferences: Rio de Janeiro.

Firestone, D., Stier, R.F., Blumenthal, M.M. (1991). Regulation of frying fats and oils. Food Technology, 45(2), 90-94.

Gunstone, F.D. (1996). Fatty Acid and Lipid Chemistry. Chapman e Hall: London, UK.

Hemalatha, S., Ghafoorunissa, S.H. (2007). Sesame lignans enhance the thermal stability of edible vegetable oils. Food Chemistry, 105(3), 1076-1085.

Hossain, M.V., Barry-Ryan, C., Martin-Diana, A.B., Brunton, N. (2010). Effect of drying method on the antioxidant capacity of six Lamiaceae herbs. Food Chemistry, 123(1), 85-91.

Krishnaiah, D., Sarbatly, R., Nithyanandam, R. (2011). A review of the antioxidant potential of medicinal plant species. Food and Bioproducts Processing, 89(3), 217233.

Kulas, E., Ackman, R. (2001). Different tocopherols and the relationship between two methods for determination of primary oxidation products in fish oil. Journal of Agricultural and Food Chemistry, 49(4), 1724-1729.

Luzia, D.M.M., Jorge, N. (2013). Fatty acids profile and alteration of lemon seeds extract (Citrus limon) added to soybean oil under thermoxidation. Journal of Food Science and Technology, 50(5), 965-971.

Pantzaris, T.P. (1998). Comparison of monounsaturated and polyunsaturated oils in continuous frying. Grasas y Aceites, 49(3-4), 319-325.

Pukalskas, A., Beek, T.A., Waard, P. (2005). Development of a triple hyphenated HPLCradical scavenging detection-DAD-SPENMR system for the rapid identification of antioxidants in complex plant extracts. Journal of Chromatography, 1074(1-2), 8188.

Ramalho, V.C., Jorge, N. (2008). Antioxidant action of Rosemary extract in soybean oil submitted to thermoxidation. Grasas $y$ Aceites, 59(2), 128-131.

Shan, B., Cai, Y.Z., Sun, M., Corke, H. (2005). Antioxidant capacity of 26 spice extracts and characterization of their phenolic constituents. Agricultural and Food Chemistry, 53(20), 7749-7759.

Silva, A.C., Jorge, N. (2014). Influence of Lentinus edodes and Agaricus blazei extracts on the prevention of antioxidant and retention of tocopherols in soybean oil in an accelerate storage test. Journal of Food Science and Technology, 51(6),12081212.

Simon, J.E., Morals, M.R., Phippen, W.B., Vieira, R.F., Hao, Z. (1999). Basil: A source of aroma compounds and a popular culinary and ornamental herb. In J. Janick (Ed.), Perspectives on new crops and new uses. ASHS Press: Alexandria.

Srinivasan, K. (2005). Role of spices beyond food flavoring: Nutraceuticals with multiple health effects. Food Reviews International, 21(2), 167-188.

Suja, K.P., Abraham, J.T., Thamizh, S.N., Jayalekshmy, A., Arumughan, C. (2004). Antioxidant efficacy of sesame cake extract in vegetable oil protection. Food Chemistry, 84(3), 393-400.

Velasco, J., Dobarganes, M.C. (2002). Oxidative stability of virgin olive oil. European Journal of Lipid Science and Technology, 104(9-10), 661-676.

Wannissorn, B., Jarikasem, S., Siriwangchai, T., Thubthimthed, S. (2005). Antibacterial properties of essential oils from Thai 
medicinal plants. Fitoterapia, 76(2),233236.

Yanishlieva, N.V., Marinova, E.M., Gordon, M.H., Raneva, V.G. (1999). Antioxidant activity and mechanism of action of thymol and carvacrol in two lipid systems. Food Chemistry, 64(1), 59-66.

\section{Acknowledgment}

The authors would like to thank the National Council of Scientific and Technological Development - CNPq, for the Productivity Scholarship. 